\title{
Association between inflammatory mediators, grip strength and mobility in community-dwelling elderly
}

\author{
Associação entre mediadores inflamatórios, força de \\ preensão manual e mobilidade em idosos da comunidade
}

\author{
Asociación entre mediadores inflamatorios, fuerza de \\ la empuñadura y la movilidad en ancianos de la comunidad
}

\author{
Barbara Gazolla de Macedo ${ }^{[a]}$, Hanna Sette Câmara de Oliveira ${ }^{[a]}$, Marielle Viotti de Paula ${ }^{[a]}$, \\ Gisele de Cássia Gomes ${ }^{[b]}$, Carlos Maurício de Figueiredo Antunes ${ }^{[a, c]^{*}}$
}

[a] Instituto de Ensino e Pesquisa da Santa Casa de Belo Horizonte (IEP SCBH), Belo Horizonte, MG, Brazil

[b] Universidade Federal de Minas Gerais (UFMG), Belo Horizonte, MG, Brazil

[c] Johns Hopkins University School of Public Health (JHSPH), Baltimore, Maryland, United States

\begin{abstract}
Introduction: Aging is associated with loss of muscle mass, immunosenescence and increased production of inflammatory mediators, high levels being predictors of a decline in functional capacity in the elderly. Objective: To assess the association between inflammatory mediators, interleukin 6 (IL-6) and C-reactive protein (CRP) and functional capacity in the elderly. Methods: Cross-sectional study with 308 communitydwelling elderly. The study was approved by the Research Ethics Committee, under protocol number $067 / 2010$. Grip strength (GS) was measured using a JAMAR ${ }^{\circledR}$ dynamometer and functional capacity by
\end{abstract}

*BGM: Doctoral student, e-mail: barbaragazolla@terra.com.br

HSCO: BS, e-mail: hannasette@hotmail.com

MVP: BS, e-mail: marivito@hotmail.com

GCG: PhD, email: giselecg@ufmg.br

CMFA: PhD, e-mail: antunesc@santacasabh.com.br 
the Timed Up and Go (TUG) test. Blood tests were performed and serum levels of C-reactive protein and interleukin 6 assessed. Spearman's coefficient was applied to analyze the correlation between variables and the Mann-Whitney for intergroup comparison. Significance was set at 0.05 . Results: There was no significant correlation between GS, the TUG and inflammatory mediators (CRP and IL-6). However, by adjusting for variables such as age, sex and muscle mass, a significant and inverse correlation $(p=0.023)$ was observed between GS and CPR. Conclusion: Elderly subjects with low C-reactive protein levels performed better in the grip strength test. It is important to investigate the adverse effects on functional capacity that can be influenced by inflammatory cytokines in the elderly during aging.

Keywords: Inflammatory Mediators. Functional Capacity. Aging. Elderly.

\section{Resumo}

Introdução: $O$ envelhecimento está relacionado a perda de massa muscular, imunossenescência e o aumento da produção de mediadores inflamatórios, cujos níveis elevados são preditores do declínio da capacidade funcional na população idosa. Objetivo: Avaliar a associação entre mediadores inflamatórios, interleucina-6 (IL-6) e proteína C-reativa (PCR) e capacidade funcional no idoso. Métodos: Estudo transversal com 308 idosos da comunidade. $O$ estudo foi aprovado pelo Comitê de Ética e Pesquisa, 067/2010. A força de preensão manual (FPM) foi avaliada através do dinamômetro de JAMAR® e a capacidade funcional pelo teste Timed Up and Go. Foi realizado um exame de sangue e analisados os níveis séricos de proteína C-reativa e interleucina-6. Utilizou-se o coeficiente de Spearman para verificar a correlação entre as variáveis e o teste de Mann-Whitney para comparação entre os grupos. O nível de significância utilizado foi de 0,05. Resultados: Não houve correlação significativa entre a FPM e o Timed Up and Go e os mediadores inflamatórios (PCR e IL-6). Porém, ao controlar as variáveis como idade, gênero e índice de massa muscular encontrou-se uma associação significativa e inversa $(p=0,023)$ entre a FPM $e$ os níveis de PCR. Conclusão: Idosos com baixos índices de proteína C-reativa apresentaram melhor desempenho no teste de força muscular manual. É destacável a importância da investigação dos desfechos adversos que podem ser influenciados pela citocinas inflamatórias na capacidade funcional dos idosos durante o envelhecimento.

Palavras-chave: Mediadores Inflamatórios. Capacidade Funcional. Envelhecimento. Idosos.

\section{Resumen}

Introducción: El envejecimiento se relaciona con una pérdida de masa muscular, inmunosenescencia, tanto el aumento de la producción de mediadores inflamatorios, cuyos niveles elevados son predictores de disminución de la capacidad funcional en la población de edad avanzada. Objetivo: Investigar la asociación entre mediadores inflamatorios, interleucina-6 (IL-6) y proteína C reactiva (CRP) y capacidad funcional en los ancianos. Métodos: Estudio transversal con 308 ancianos de la comunidad. El estudio fue aprobado por el Comité de Ética e Investigación, 067/2010. La fuerza de la empuñadura (GS) se evaluó utilizando el dinamómetro JAMAR® y la capacidad funcional mediante la prueba Timed Up and Go. Se realizó un análisis de sangre y se analizaron los niveles séricos de proteína C reactiva e interleucina-6. El coeficiente de Spearman se utilizó para verificar la correlación entre las variables y la prueba de Mann-Whitney para la comparación entre los grupos. El nivel de significancia fue 0,05. Resultados: No hubo correlación significativa entre GS y Timed Up and Go y mediadores inflamatorios (CRP e IL-6). Sin embargo, cuando se controlaron variables como la edad, el sexo y el índice de masa muscular, hubo una asociación significativa ( $p=0,023)$ entre los niveles de GS y CRP, es decir, los individuos que obtuvieron buenos resultados en el GS obtuvieron niveles más bajos de PCR circulante. Conclusión: Los pacientes ancianos con bajos niveles de proteína C reactiva, presentaron mejor desempeño en la prueba de fuerza muscular manual. Es importante investigar los efectos adversos que pueden estar influenciados por las citosinas inflamatorias sobre la capacidad funcional de los ancianos durante el envejecimiento.

Palabras clave: Mediadores Inflamatorios. Capacidad Funcional. Envejecimiento. Madurez. 


\section{Introduction}

The world is experiencing a demographic transition. Recent global population data published by the World Health Organization (WHO) indicate that 1 in every 10 people is aged 60 years or older, a figure that is expected to rise to 1 in 5 by 2050, with approximately 2.1 billion people in this age group [1]. Estimates suggest that Brazil's population in 2050 will be the fifth largest in the world [2].

One of the consequences of this demographic shift is the simultaneous increase in chronic health problems. By 2020, chronic conditions will be the primary cause of incapacity (80\%) worldwide and a major problem for health care systems [3].

Senescence, or aging, is a dynamic process that involves physiological, psychological and biochemical losses and a heightened risk of chronic disease, which can lead to declines in a range of different areas. Aging is characterized as a progressive and linear decline in bodily functions [3].

Worldwide, more than $46 \%$ of those aged 60 years or older exhibit disabilities. Poor performance in activities of daily living that require mobility and locomotion are common in older adults, affecting an estimated $20-30 \%$ of community-dwelling elderly over 70 years old [4].

Functional capacity (FC) was defined by Camara [5] as "the ability to efficiently respond to everyday physical demands, including everything from the basic activities required for independence to more complex tasks". As part of the aging process, FC decreases due to declining physical abilities and changes in the muscular, bone, cardiorespiratory and nervous systems. The combined dysregulation of these systems affects performance in routine activities in this population [5].

Authors suggest that every year up to $10 \%$ of individuals aged 75 years or older lose their independence in activities of daily living, requiring greater care and assistance. Efficient clinical indices are needed to allow early interventions aimed at identifying functionally compromised elderly [6]. Functional impairment may be related to decreased strength and muscle mass, leading to a greater risk of falls, dependence and mortality in the elderly [7 - 10].

Another relevant negative effect of aging is immunosenescence, which involves the gradual deterioration of the immune system. These changes are characterized by an increase in the production of proinflammatory cytokines, causing chronic inflammation in the elderly. Although immunity may appear preserved, the increase in these cytokines is associated with high levels of morbidity and mortality in this population [11]. Some authors report that a rise in inflammatory cytokines is the result of immunosenescence, low physical activity levels and sarcopenia, even without the presence of associated diseases $[8,9,12]$.

However, Penninx et al. [12] found that high inflammatory cytokine levels are present in acute and chronic conditions such as coronary diseases, congestive heart failure, atherosclerosis and arthrosis, comorbidities with a high prevalence among the aged population. Queiroz [13] reports that this increase can be triggered by weight gain, decreased production of sex hormones, smoking, extreme stress, depression and pain.

Cytokines, low molecular weight glycoproteins secreted by different cells of the body, play an important role in this process as inflammatory mediators (biomarkers) that control the duration and intensity of inflammation, capable of acting at or near the sites where they are produced, or being released into the bloodstream [14]. Chronic inflammation, which persists over longer periods, seems to have a harmful effect on the body $[8,12]$.

The occurrence of persistent low-grade inflammation characterized by high inflammatory mediator levels is common at advanced ages. Interleukin 6 (IL-6) and C-reactive protein (CRP) are among the most widely studied cytokines and acute-phase proteins present in these inflammatory conditions. Inflammation is the result of an imbalance in pro- and antiinflammatory substances in the body [15]. High levels of proinflammatory mediators, frequently observed in healthy elderly individuals, contribute to loss of muscle mass and strength and are a precursor of functional decline, dependence, cardiovascular events and severe diseases $[7,13,15]$.

IL-6, known as the "geriatric cytokine", is produced during trauma and infection, but high serum levels are observed in the elderly. Research has shown that prolonged inflammation may be negatively associated with strength, mass, and functional performance in the elderly [8 - 10, 12].

C-reactive protein is also related to the inflammatory process and plays a vital role in the immune mechanism of aged individuals [16]. High CRP levels are related to functional losses and disabilities [17], including cognitive deficits, vascular dementia and Alzheimer's [18].

Some studies have demonstrated an association between high inflammatory mediator levels and 
reduced mobility, as well as a decline in the ability to perform activities of daily living $[8,12]$.

The performance of elderly individuals in routine tasks is affected by a number of different variables. Physical tests and questionnaires aimed at measuring the functional capacity of these individuals are important because they predict possible longitudinal changes in FC and can be used to assess the interventions applied [5].

The grip strength (GS) test is widely used [5, 8, $17,19]$ and seems to reliably demonstrate loss of muscle strength in other muscle groups. Authors such as Camara et al. [5] have reported that the decline in strength with age can cause repercussions such as increased disability, morbidity and mortality in this population. Research has shown that GS can predict reduced functional capacity and mobility, as well as falls and even death in the elderly $[5,8,19]$.

Another widely used mobility test to assess FC in older adults is the Timed Up and Go (TUG). Its simplicity, easy application and low cost make it highly useful in clinical contexts. The TUG assesses aspects of functional ability, such as mobility and balance, and qualifies performance according to the time taken to perform the proposed task. With an ICC of $\mathrm{r}=0.99$, it is described as a good predictor of disability, morbidity and mortality among the elderly [5].

The aim of this study was to investigate associations between inflammatory mediator levels (IL-6 and CRP) and functional capacity (GS and TUG) in communitydwelling elderly individuals.

\section{Methods}

\section{Study Design and Participants}

This is a cross-sectional study with 308 randomly selected elderly individuals visiting a medical specialty center in Belo Horizonte for a doctor's consultation or rehabilitation. Inclusion criteria were: aged 60 years or older and able to walk independently, with no gender or ethnicity restrictions. Older adults who had undergone surgery in the 6 months prior to data collection, been diagnosed with cancer, exhibited stroke sequelae, suffered from Parkinson's disease or neurological conditions affecting mobility and cognition, severe or decompensated heart failure, severe or decompensated chronic obstructive pulmonary disease, or had been hospitalized in the last 6 months were excluded. The study was approved by the Research
Ethics Committee (COEP) under protocol number 067/2010. Data were collected from 2013 to 2014, at a physiotherapy outpatient clinic run by the state health care network, after participants had provided written informed consent.

Sociodemographic and clinical data were collected from the participants and blood samples were taken for CRP and IL- 6 analyses conducted in a clinical analysis laboratory.

\section{Measuring instruments}

Timed Up \& Go Test (TUG)

The Timed Up and Go (TUG) test was used to assess functional capacity. The test evaluates the time needed to rise from a chair, walk three meters, turn around, walk back to the chair and sit down again, characterizing a set of everyday actions that are essential for independent mobility. Performance is affected by reaction time, muscle strength of the lower limbs, balance and gait. The cutoff points proposed by Bohannon [20] were used, whereby the estimated execution time for 60 to 69-year-olds was 8.1 (7.1-9.0) seconds; 9.2 (8.2-10.2) seconds for 70 to 79 -year-olds, and 11.3 (10.0-12.7) seconds for those aged 80 to 99 years.

\section{Grip Strength (CS)}

Grip strength was measured for the dominant arm, using a Jamar ${ }^{\circledR}$ dynamometer. The test was conducted in line with the recommendations of the American Society of Hand Therapists [21]. Participants were positioned with their shoulder adducted, elbow flexed at $90^{\circ}$, forearm in a neutral position, and wrist between $0^{\circ}$ and $30^{\circ}$ extension and $0^{\circ}$ and $15^{\circ}$ of ulnar deviation. They were verbally encouraged to squeeze the dynamometer handle at maximum strength with their dominant hand for six seconds. Three measurements were taken, with a 60 -second rest between them, and the highest of the three was used in the analysis. The grip strength reference values proposed by Fried et al. [22] and adjusted according to body mass index (BMI) were used in this study.

\section{Inflammatory Markers}

In order to determine serum levels of the proinflammatory cytokines CRP and IL-6, blood samples were collected by a specialized laboratory, which conducted a complete blood count for each participant and obtained serum CRP levels. Part of the samples (10 mL of blood) was sent to the Santa Casa Research 
and Extension Studies Institute (IEP) in Belo Horizonte (Minas Gerais state - MG), where it was centrifuged, and the plasma removed, stored and sent for analysis. Serum IL-6 levels were measured using an ultrasensitive ELISA kit for human IL-6 at the Research Laboratory of the Federal University of Minas Gerais (UFMG), in accordance with the manufacturer's recommendations, and expressed as picograms per milliliter $(\mathrm{pg} / \mathrm{mL})$.

\section{Statistical Analysis}

The mean, standard deviation, first, second and third quartiles were calculated to describe the quantitative variables and the minimum and maximum values presented. Variables with non-normal distribution were submitted to Spearman's correlation or the Mann-Whitney test (Hollander and Wolfe, 1999). Spearman's correlation is a limited measure between -1 and 1 , whereby the closer the coefficient is to - 1 , the greater the negative correlation, and the closer it is to 1 , the greater the positive correlation. The analyses were conducted using R software (version 3.3.3) and the Hmisc and Ggplot packages. Qualitative variables were expressed as absolute and relative frequencies.

\section{Results}

In a sample of 308 participants with an average age of 70.6 years (age range of 60 to 94 years), $78.2 \%$ were women and $63 \%$ were white. Of these, $41.9 \%$ were married and $26.9 \%$ widowed, with an average of $90 \%$ retired and $19.2 \%$ still employed. Only $5.5 \%$ of subjects reported they were smokers. The mean BMI for all participants was 27.4. Approximately $92.5 \%$ of the elderly subjects reported some form of comorbidity. Mean values for IL- 6 and CRP were $4.0 \mathrm{mg} / \mathrm{L}$ and $3.8 \mathrm{pg} / \mathrm{mL}$, respectively.
The quantitative variables GS and TUG were classified in terms of good or poor performance, with $78 \%$ performing well in the GS assessment and $43.8 \%$ poorly in the TUG test. The characteristics of the population according to sociodemographic and clinical data are shown in Tables 1 and 2.

Table 1 - Frequency and qualitative variables

\begin{tabular}{|c|c|c|}
\hline Variables & & Frequency \% \\
\hline \multirow{2}{*}{ Gender } & Female & 241 \\
\hline & Male & 67 \\
\hline \multirow{4}{*}{ Skin Color } & Yellow & 7 \\
\hline & White & 194 \\
\hline & Negro & 49 \\
\hline & Mulatto & 58 \\
\hline \multirow{4}{*}{ Civil Status } & Married & 129 \\
\hline & Divorced & 43 \\
\hline & Single & 53 \\
\hline & Widower & 83 \\
\hline \multirow{2}{*}{ Presently Employed } & No & 249 \\
\hline & Yes & 59 \\
\hline \multirow{2}{*}{ Retired } & No & 30 \\
\hline & Yes & 278 \\
\hline \multirow{2}{*}{ Presently Smoker } & No & 291 \\
\hline & Yes & 17 \\
\hline \multirow{2}{*}{ Co-morbidites } & No & 23 \\
\hline & Yes & 285 \\
\hline \multirow{2}{*}{ Grip Strenght Test } & Adequate & 237 \\
\hline & Insufficient & 67 \\
\hline \multirow{2}{*}{ TUG Test } & Adequate & 173 \\
\hline & Insufficient & 135 \\
\hline
\end{tabular}

Note: Belo Horizonte, MG, 2014. 
Table 2 - Means and quantitative variables

\begin{tabular}{|c|c|c|c|c|c|c|c|c|}
\hline Variables & $\mathbf{N}$ & Means & Standard deviation & Minimum & $1^{\circ} Q$ & $2^{\circ} Q$ & $3^{\circ} \mathrm{Q}$ & Maximum \\
\hline Age (years) & 308 & 70.6 & 6.8 & 60 & 66 & 69 & 75 & 94 \\
\hline Education (years) & 302 & 9.7 & 5.0 & 0 & 5 & 10 & 12 & 28 \\
\hline IMC $\left(\mathrm{kg} / \mathrm{m}^{2}\right)$ & 304 & 27.4 & 4.8 & 16.8 & 24.1 & 27.1 & 30.2 & 45.6 \\
\hline Grip Strength (kgf) & 306 & 23.3 & 7.6 & 10 & 18 & 22 & 28 & 50 \\
\hline TUG (seconds) & 304 & 10.2 & 2.7 & 4 & 9 & 10 & 11 & 24 \\
\hline CRP (picogram/mL) & 293 & 3.8 & 4.7 & 0.1 & 0.8 & 2.1 & 4.9 & 32.1 \\
\hline IL-6 (mg/L) & 294 & 4.0 & 4.9 & 0.0 & 0.9 & 2.6 & 5.0 & 32.0 \\
\hline
\end{tabular}

Note: Belo Horizonte, MG, 2014.

Assessment of the correlation between inflammatory variables and functional capacity using Spearman's test showed no significant correlations between the TUG and IL-6 and CRP. There was also no evidence of a correlation between GS and IL-6 and CRP (Table 3).

Table 3 - Correlation between CRP, IL-6 and Grip Strength Test, TUG

\begin{tabular}{lcc}
\hline Variables & Correlation Coeficient Spearman & P-value \\
\hline CRP x Grip Strength & -0.051 & 0.380 \\
CRP x TUG & 0.067 & 0.254 \\
IL-6 x Grip Strength & -0.034 & 0.558 \\
IL-6 x TUG & 0.052 & 0.378 \\
\hline
\end{tabular}

Note: Belo Horizonte, MG, 2014.

Given the non-significant correlation in the quantitative assessment of the functional capacity tests (TUG and GS), the variables were categorized to determine the existence of a difference in the distribution of inflammatory mediators between good and poor performance.

The TUG groups were formed using the classification criteria proposed by Bohannon [20], adjusted in accordance with the age range of participants. No significant difference was observed for CRP distribution in these groups (Table 4).

Performance in the GS test was classified as good or poor based on the criteria of Fried et al. [22]. A significant intergroup difference in CRP distribution was observed, with lower values recorded in the group that performed well in the GS test when compared to those who performed poorly (Table 4). 
Table 4 - Grip Strength, TUG and CRP level

\begin{tabular}{|c|c|c|c|c|c|c|c|c|}
\hline \multirow[b]{2}{*}{ Variables } & \multicolumn{8}{|c|}{ PCR } \\
\hline & & N & Means & $\begin{array}{l}\text { Standard } \\
\text { deviation }\end{array}$ & $1^{\circ}$ Quartile & $2^{\circ}$ Quartile & $3^{\circ}$ Quartile & P-value* \\
\hline \multirow{3}{*}{ Grip Strength } & Adequate & 227 & 3.59 & 0.30 & 0.70 & 1.78 & 4.84 & \\
\hline & & & & & & & & 0.023 \\
\hline & Insufficient & 65 & 4.69 & 0.66 & 1.09 & 2.95 & 5.80 & \\
\hline \multirow{3}{*}{ TUG } & Adequate & 166 & 3.66 & 0.36 & 0.76 & 1.97 & 4.83 & \\
\hline & & & & & & & & 0.665 \\
\hline & Insufficient & 127 & 4.04 & 0.43 & 0.74 & 2.23 & 5.18 & \\
\hline
\end{tabular}

Note: Belo Horizonte, MG, 2014. * Significance 5\%, Mann-Whitney Test.

No significant intergroup differences in IL-6 distribution were recorded for good and poor grip strength or between performance groups in the TUG (Table 5).

Table 5 - Grip Strength, TUG and IL-6 level

\begin{tabular}{|c|c|c|c|c|c|c|c|c|}
\hline \multirow[b]{2}{*}{ Variables } & \multicolumn{8}{|c|}{ IL-6 } \\
\hline & & N & Means & $\begin{array}{l}\text { Standard } \\
\text { deviation }\end{array}$ & $1^{\circ}$ Quartile & $2^{\circ}$ Quartile & $3^{\circ}$ Quartile & P-value* \\
\hline \multirow[b]{2}{*}{ Grip Strength } & Adequate & 228 & 3.76 & 0.31 & 0.85 & 2.49 & 4.52 & \multirow[b]{2}{*}{0.084} \\
\hline & Insufficient & 65 & 5.01 & 0.72 & 0.95 & 3.38 & 6.76 & \\
\hline \multirow[b]{2}{*}{ TUG } & Adequate & 166 & 3.86 & 0.35 & 0.79 & 2.69 & 5.41 & \multirow[b]{2}{*}{0.939} \\
\hline & Insufficient & 128 & 4.23 & 0.48 & 0.96 & 2.63 & 4.76 & \\
\hline
\end{tabular}

Note: Belo Horizonte, MG, 2014. * Significance 5\%, Mann-Whitney Test. 


\section{Discussion}

This study aimed to assess the relationship between serum levels of inflammatory mediators and functional capacity in the elderly. A quantitative assessment found no significant correlation between either of the functional tests (TUG and GS) and the inflammatory mediators (PCR and IL-6). However, a significant relationship was observed in the distribution differences between the good and poor GS performance groups and CRP levels, that is, those who performed well in the GS test had higher circulating CRP levels. This variable was qualitatively assessed after adjustment for BMI and age, as defined by Fried et al. [22]. Dong et al. [6] also related the grip strength test to BMI and sex. It is important to note that, unlike the test used to measure IL- 6 , those that quantify CRP are more accessible and widely used in clinical practice. In light of these findings, increased serum CRP levels should be investigated more carefully.

Our results are similar to those found in the literature. Pereira et al. [19] studied 130 community-dwelling elderly individuals and analyzed the cytokine IL-6, grip strength and the timed up and go test. The authors found a relationship between the functional tests applied, with similar physical aptitude results, but there were no significant correlations between the inflammatory mediator and GS performance. Felício et al. [9] studied the association between IL- 6 and GS in 221 communitydwelling elderly and found no significant correlations. In a study with 919 older adults aged 65 to 101 years, Rantanen et al. [23] evaluated the relationship between IL- 6 and CRP and the GS test and observed a significant correlation between participants with high inflammatory mediator levels and those with low grip strength.

As observed in the present study, these findings can be explained by the fact that the population consisted of independent community-dwelling elderly with no significant cognitive decline, which would result in lower circulating inflammatory mediator levels and better functionality indices. Another factor that may have influenced the outcome is the cutoff point for inflammatory mediators, which may not have reached levels high enough to affect functional capacity. The mean serum CRP and IL-6 levels recorded in the present study were $4 \mathrm{mg} / \mathrm{L}$ and $3.8 \mathrm{pg} / \mathrm{mL}$, respectively. There is no consensus in the literature regarding the cutoff points of mediators that predict adverse functional outcomes, and data for Brazil are scarce and conflicting. Felício et al. $[9,10]$ reported that the functional changes caused by inflammatory mediators occur at cell level before reaching the peripheral muscle tissue and generating damage such as limited mobility.

By contrast, other studies have shown found significant correlations between inflammatory mediators and functional capacity. In a study of 63 community-dwelling elderly, with an average age of 71.2 years, Pereira etal. [8] found an inverse correlation between IL-6 levels and GS. Bautmans et al. [17] studied a population of 274 older adults, with an average age of 76.4 years, and observed that GS was significantly related to IL-6 levels in men and that IL-6 was associated with perceived fatigue in women. However, the level of inflammatory mediators was not evident (CRP $<3 \mathrm{mg} / \mathrm{l}$ ). Ferrucci et al. [24] also demonstrated an association between high levels of inflammatory cytokines and reduced muscle strength, and the resulting functional decline. In his thesis, Queiroz [13] described the relationship between mediators, functionality and back pain. In a recent study, Sousa et al. [19] analyzed 1,371 elderly individuals in an international study sample and found that high CRP levels were related to poor grip strength, although this significance disappears when other covariates are adjusted.

In the present study, functional capacity was assessed using the TUG and GS because, according to Camara et al. [5], GS alone is not effective at satisfactorily predicting impairment since strength does not incorporate all the factors that define functional capacity, such as mobility, balance and agility. Additionally, Lauretani et al. [25] proposed that more than one test is needed to assess functional capacity in older adults with secondary sarcopenia. The author defined secondary sarcopenia as a condition in which loss of muscle mass cannot be explained solely by aging and physical inactivity, but rather the coexistence of associated diseases. The prevalence of comorbidities was high in our sample, with $92.5 \%$ of participants suffering from some form of acute or chronic disease. As such, they could be categorized as having secondary sarcopenia and two functional tests were therefore applied.

On the other hand, some authors indicate that mediators increase with age, even without the presence of associated comorbidities. This is a natural process caused by immunosenescence and sarcopenia. According to Ershler \& Keller [26], this rise in IL-6 in healthy elderly people is caused by the decline in sex steroids, typically IL-6 inhibitors, making increased IL-6 a physiological outcome.

In a study by Ferrucci et al. [24], increased IL-6 levels occurred due to the decline in anabolic stimulant, reducing the synthesis of muscle proteins and leading 
to sarcopenia. Recent data indicate that IL-6 inhibits the production of insulin-like growth factor 1 , an anabolic muscle stimulant. These findings reveal that high levels of cytokines can contribute to sarcopenia. Pereira et al. [8], Fougere et al. [7], Queiroz [13], and Bautmans et al. [17] reported that medication, physical activity levels, common diseases, nutrition, obesity, diabetes and smoking can cause variations in mediator values and directly affect sarcopenia. The mean BMI in our population was 27.4, indicating a prevalence of overweight individuals, although only 5.5\% reported they were smokers. Data on nutritional status, current physical activity level and specific diseases were not collected. The high number of elderly individuals with comorbidities demonstrates that this population probably uses several drugs. All these factors are related to sarcopenia and circulating inflammatory mediators and may have influenced the results.

Penninx et al. [12] demonstrated that the relationship between low-grade inflammation in aging and inflammatory cytokines becomes more significant when different inflammatory mediators are assessed because it increases the specificity of inflammation and better predicts physical decline than high levels of single markers. Two widely studied inflammatory mediators related to the elderly and proinflammatory cytokines were assessed in the present study.

Interleukin 6 (IL-6), known as the "geriatric cytokine", is the most frequently cited in the literature. There is consistent scientific evidence demonstrating that IL-6 is related to sarcopenia and persistent lowgrade inflammation in the elderly and their relationship with limited mobility, disabilities, falls, morbidity and mortality [7, 8, 12, 15, 16, 17, 19]. C-reactive protein (CRP), an acute-phase protein, is also associated with these processes and seems to have a strong relationship with IL-6 [7, 17]. High levels of both are typical in immunosenescence, sarcopenia, and inflammatory conditions caused by chronic diseases [27].

The study population consisted of independent elderly individuals, with 78\% obtaining good results in the GS test. By contrast, almost half (43.8\%) performed poorly in the TUG, indicating that strength may have had little influence on TUG performance, and that other aspects of functional capacity, such as those described by Camara et al, might have affected the results. Camara et al5 demonstrated that assessing functional capacity based on the complexity of everyday actions should include a variety of areas, such as gait, mobility, balance, strength and quantitative analyses of movement.
According to the author, although this requires more resources and makes large-scale application difficult, it provides a comprehensive and effective assessment.

The fact that a majority of the sample were women, who live longer and show higher levels of disability [28], may have influenced the poor performance in the TUG. Pereira et al. [8] and Felício et al. [9, 10] found that impaired functional capacity is more prevalent in women. The author used all-female samples in his research to prevent gender bias in relation to muscle strength and health status and because woman represent the largest portion of the elderly population. By contrast, Dong et al. [6] found different losses in the upper and lower limbs of women, who experience a slower decline in muscle strength in the arms when compared to the legs. This may have influenced the large number of low TUG results and high levels of good GS performance, as occurred in the present study.

The present study exhibits some limitations. Information was not collected on disease severity, nutritional status, physical activity level, medication, stress levels, depression and pain, which may have affected the findings. Patients with acute inflammatory conditions were not excluded, which may have influenced the inflammatory mediator results. Additionally, the cross-sectional design made it impossible to measure the long-term effects of the increase in inflammatory mediators.

It is important to conduct an accurate clinical assessment in order to study the functional changes that occur during senescence with a view to creating more targeted and efficient preventive measures and initiatives to ensure better quality of life and lower levels of disability, falls, morbidity and mortality in the elderly population.

\section{Conclusion}

No significant associations were found between inflammatory mediators and functional capacity assessed by the TUG testand grip strength in communitydwelling elderly subjects; however, a significant difference was observed between CRP distribution and grip strength. This complex relationship should be investigated in future studies.

More significant determinations of broader correlation studies are needed in order to recommend the investigation of inflammatory cytokines in clinical assessment aimed at determining the risk of frailty in the elderly, which remains controversial in the literature. 


\section{References}

1. United Nations, Department of Economic and Social Affairs, Population Division. World Population Ageing. 2015. [cited 2017 Mar 22]. Available from: http://www. un.org/en/development/desa/population/

2. IBGE - Instituto Brasileiro de Geografia e Estatística. [cited 2017 Feb 22]. Available from: http://www. ibge.gov.br

3. Cuidados inovadores para condições crônicas: componentes estruturais de ação: relatório mundial / Organização Mundial da Saúde - Brasília, 2003 Available from: https://www.opas.org.br/wpcontent/ uploads/2015/09/Manualfinal.pdf [cited 2017 Feb 26].

4. Camargo ABM, Saad PMA. A transição demográfica no Brasil e seu impacto na estrutura etária da população. SEADE. O idoso na Grande São Paulo. 1990; p. 9-25.

5. Camara FM, Gerez AG, Miranda MLJ, Velardi M. Capacidade funcional do idoso: formas de avaliação e tendência. ActaFisiátrica. 2008;15(4): 249-256.

6. Dong R, Wang X, Guo Q Wang J, Zhang W, Shen S et al. Clinical relevance of different handgrip strength indexes and mobility limitation in the elderly adults. J Gerontol A Biol Sci Med Sci. 2016;71(1):96-102. doi: 10.1093/ gerona/glv168.

7. Fougère B, Vellas B, van Kan GA, Cesari M. Identification of biological markers for better characterization of older subjects with physical frailty and sarcopenia. Transl Neurosci. 2015;6(1):103-110.

8. Pereira LS, Narciso FM, Oliveira DM, Coelho FM, Souza DG, Dias RC. Correlation between manual muscle strength and interleukin 6 (IL-6) plasma levels in elderly community-dwelling women. Arch Gerontol Geriatr. 2009;48(3):313-6. doi: 10.1016/j.archger.2008.02.012.

9. Felício DC, Pereira DS, Assumpção AM, Jesus-Moraleida FR, Queiroz BZ, Silva JPet al. Inflammatory mediators, muscle and functional performance of communitydwelling elderly women. Arch Gerontol Geriatr. 2014; 59(3):549-553. doi: 10.1016/j.archger.2014.08.004.

10. Felício DC et al. Systemic inflammation and physical function in community elderly women. Inflamm and Cells Signal. 2014;1(4):e368. doi: 10.14800/ics.368.
11. Agondi RC, Rizzo LV, KalilJ,Barros MT.Imunossenescência. Rev. Bras. Alerg. Imunopatol. 2012;35(5):169-176.

12. Penninx BW, Kritchevsky SB, Newman AB, Nicklas BJ, Simonsick EM, Rubin S, et al. Inflammatory markers and incident mobility limitation in the elderly. J Am Geriatr Soc. 2004 Jul;52(7):1105-13.

13. Queiroz BZ. Mediadores inflamatórios, sarcopenia, funcionalidade e dor lombar aguda em idosas: estudo longitudinal Back Complaints in the Elders Brasil. Tese (Doutorado em Fisioterapia) Belo Horizonte - Escola de Educação Física, Fisioterapia e Terapia Ocupacional, Universidade Federal de Minas Gerais, Belo Horizonte; 2015.

14. Kraychete DC, Calasans MTA, Valente CML. Citocinas Próinflamatórias e dor. Rev. Bras. Reumatol. 2006; 46(3): 199-206.

15. Franceschi C, Campisi J. Chronic inflammation (inflammaging) and its potential contribution to ageassociated diseases. J Gerontol A Biol Sci Med Sci. 2014;69(S1):S4-S9.

16. Caúla AL, Fischer RG. Relação entre a proteína C reativa sistêmica e a doença periodontal. Revista Periodontia. 2004;14(3):18-24.

17. Bautmans I, Gorus E, Njemini R, Mets T et al. Handgrip performance in relation to self perceives fatigue, physical functioning and circulating IL-6 in elderly persons without inflammation. BMC Geriatrics. 2007;7:5.

18. Komulainen P, Lakka TA, Kivipelto M, Hassinen M, Penttilä IM, Helkala EL et al. Serum high sensitivity C-reactive protein and cognitive function in elderly women. Age Ageing. 2007;36:443-8.

19. Pereira DS, Cipriano VF, Amorim, JSC, Queiroz BZ, Felício DC. Handgrip strength, functionality and plasma levels of IL-6 in elderly women. Fisioterapia em Movimento (PUC-PR. Impresso). 2015; 28: 477-483.

20. Bohannon RW. Reference Values for the Timed Up and Go test: a descriptive meta-analysis. J Geriatr Phys Ther. 2006;29(2):64-8.

21. American Society of Hand Therapists. Clinical Assessment Recommendations. Chicago. [cited 2017 Mar 26]. Available from: https://www.asht.org/ practice/clinicalassessmentrecommendatios 
22. Fried LP, Tangen CM, Walston J, Newman AB, Hirsch C, Gottdiener J et al. Frailty in older adults: evidence for a phenotype. J Gerontol A Biol Sci Med Sci. 2001;56(3):M146-56.

23. Rantanen T, Volpato S, Ferrucci L, Heikkinen E, Fried LP, Guralnik JM. Handgrip strength and cause-specific and total mortality in older disabled women: exploring the mechanism. J Am Geriatr. Soc. 2003;51(5):636-41.

24. Ferrucci L, Penninx BW, Volpato S, Harris TB, BandeenRoche K, Balfour J et al. Change in muscle strength explains accelerated decline of physical function in older women with high interleukin-6 serum levels. J Am Geriatr Soc. 2002;50(12):1947-54.

25. Lauretani F, Bautmans I, De Vita F, Nardelli A, Ceda GP, Maggio M. Identification and treatment of older persons with sarcopenia. Aging Male. 2014;17(4):199-204.
26. Ershler WB, Keller ET. Age-associated increased interleukin-6 gene expression, late-life diseases, and frailty. Annu Rev Med. 2000;51:245-70.

27. Sousa ACPA et al. Association between C-reative protein and physical performance in older populations: results from the International Mobility in Aging Study (IMIAS). Age and Aging. 2016; 45: 274-280.

28. Dohert TJ. Invited review: Aging and sarcopenia. J Appl Physiol 2003;95(4):1717-27.

Received in 09/12/2017

Recebido em 12/09/2017

Recibido en 12/09/2017

Approved in 05/24/2018

Aprovado em 24/05/2018

Aprobado en 24/05/2018 